CURRENT TOPICS ( 3 )

\title{
不均一系における高速反応測定法の開発とその応用
}

\author{
佐々木実・安永達也 \\ 広島大学理学部物性学科 $\mathbf{T} 730$ 広島市中区東千田町 1-1-89
}

(1984 年 7 月 23 日 受理)

\section{Development of New Techniques for Measurements of Fast Reactions in Heterogeneous Systems and Their Application}

\author{
Minoru SASAKI and Tatsuya YASUNAGA \\ Department of Material Science, Faculty of Science, \\ Hiroshima University, Hiroshima 730
}

(Received July 23, 1984)

\begin{abstract}
New Techniques are described for determining dynamic properties on fast reactions in heterogeneous systems; solid-liquid, gas-liquid, and gas-solid interfaces. Various kinds of relaxations were observed by these techniques and the detailed mechanisms on proton adsorption-desorption, counterion formation reaction, specific adsorption, and intercalation-deintercalation of alkali metal ions at solid-solution interface, surfactant adsorption-desorption and complex formation reaction at gassolution interface and coadsorption-desorption of methanol in channel of H-ZSM-5, were clarified.
\end{abstract}

吸着・イオン交換・固体触媒反応などのように，界面 における反応は基礎のみならず，応用的にも興味深いも のが多い。乙のような反応においては，界面が特異な反 応場として重要な役割を演じているが，界面と言われる 領域は極めて薄いために, 測定手段屯限られ, 均一系反 応に比べその取扱いは複雑である。その複雑さのため に, これらの研究の大半が現象論に終始し, 本質の把握 にまで至っていないというのが現状である。では，いか にてのような問題を解決していけばいいのであろうか。 著者らは, 不均一系で起こる現象を, 静止した死の世界 として見るのではなく，活き活きした動いている世界と して見ることにより，本質の理解により近づきうるとい う観点汃ら，種々の不均一系における高速反応測定法を 開発してきた。不均一系の場合, 界面の種類によって測 定原理が全く異なり, 固一液・気一液・気一固界面に大 別し，乙れらの界面で起こる高速反応の測定原理および 得られた興味ある動的知見について以下に述べる。

\section{1. 固液界面における高速反応}

\section{1 圧カジャンプ法および電場パルス法}

王力ジャンプ法とは1"，微粒子けん濁液のような不均
一系に圧力を加え, その後, 圧力を急激に降下させて系 中に存在する平衡を攪乱することにより，攪乱された平 衡が新しい平衡へ之移行する過程, いわゆる緩和過程在 電導度あるいは濁度の変化として検出する方法で, 本装 置のブロックダイヤグラムを Fig. 1 亿示す。電導度検 出の場合，本体には試料けん濁液を入れたサンプルセル

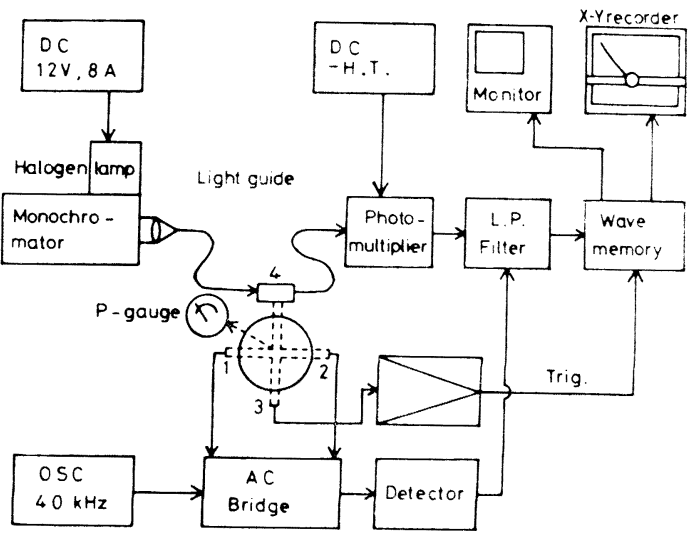

Fig. 1 Block diagram of the pressure-jump apparatus with electric conductivity detection and turbidity detections ${ }^{11}$. 
および武料と同じ電導度を有する塩溶液を入れた参照セ ルが組み込ま机ており，水圧ポンプで压力が約 100 気圧 まで上昇すると，本体に取り付けた金属薄膜が破机，両 セルに加えられた圧力が 1 気圧に降下する。乙の時の両 セルの電導度の差の時間変化を交流ブリッジで, 濁度検 出の場合には, けん濁液を透過する単色光の光量の時間 変化をフォトマルで検出する。いずれの場合も測定時間 限界は約 $100 \mu$ 秒之極めて速く，乙れよりも遅い緩和現 象は観測可能である。

Fig. 2 (a) 扔よび ( b ) はそれぞれ酸化チタンけん濁 液系で見い出した電導度および濁度の時間変化であり,

Fig. 2(a) 著者らにより世界で初めて不均一系で見い 出した緩和である ${ }^{2)}$ 。乙れらの図からわかるように，緩 和過程は濁度の著しい变化を伴なうような物理現象, 例 えば粒子の凝集ではなく, イオンの関与した固一液界面 における反応に基づくあのである。

圧力ジャンプ法による測定条件として，まず，微粒子 等が安定に分散しているとと, および, バルク相中のイ オン濃度が $10^{-4} \sim 10^{-2} \mathrm{~mol} \mathrm{dm}^{-3}$ の範团であるととが望 ましい。

一方, 電場パルス法上は ${ }^{1}$, 約数十 $\mathrm{kV}$ の高電圧によ り平衡を攪乱する，いわゆる解離場効果（第二Wien 効 果とあいう）を测定する方法であり，本装置のブロック

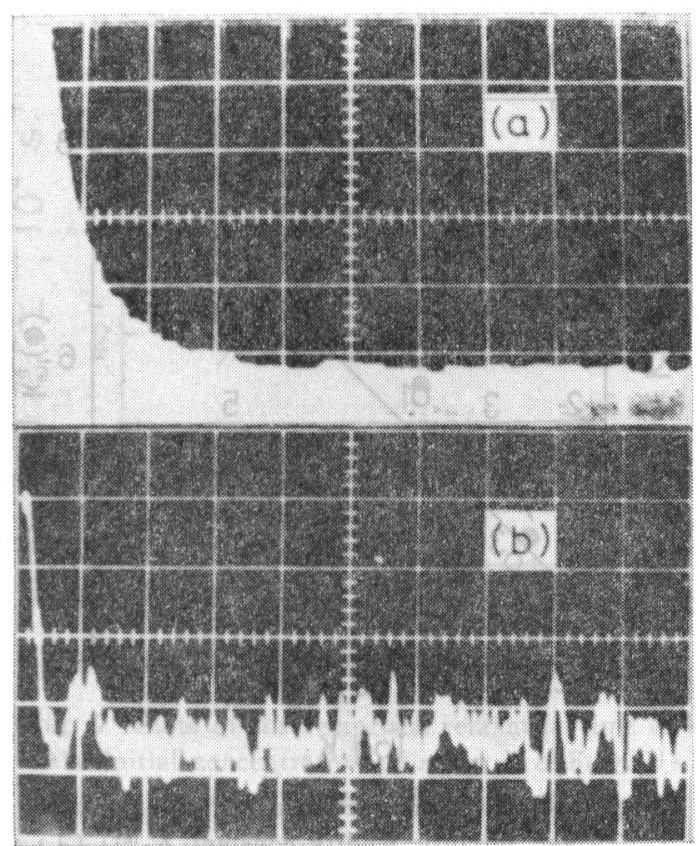

Fig. 2 Typical relaxation curve in the $\mathrm{TiO}_{2}{ }^{-}$ $\mathrm{HCl}$ system observed by the pressure-jump apparatus with conductivity (a) and turbidity (b) detections. Sweeps, $5 \mathrm{msec} / \mathrm{div}^{2}{ }^{2}$.

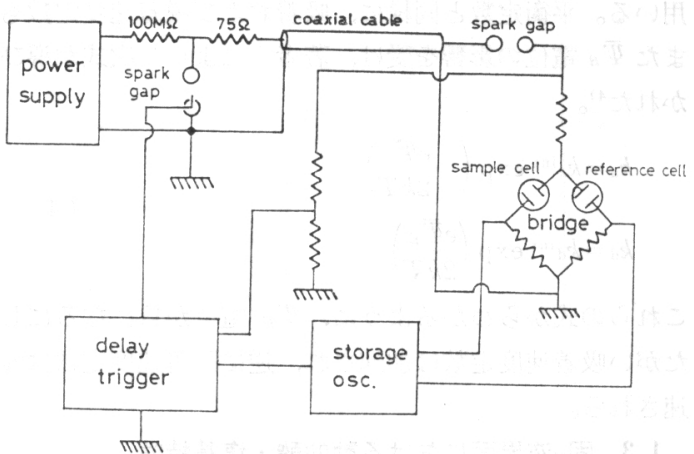

Fig. 3 Block diagram of the electric field pulse apparatus with electric conductivity detection.

ダイヤグラムを Fig. 3 に示す。高圧電源からの高電圧 をサンプルおよび参照セルに印加し，その高電圧により 両セル内で起とる解離場効果の差を差動アンプで検出す る。本装置により測定可能な時間領域は $10^{-7} \sim 10^{-4}$ 秒 で, 圧力ジャンプ法に比べて極めて速く, 低濃度の試料 中に怙ける高速反応測定に適している。

\section{2 不均一系反応速度論}

固一液界面では, 界面に電荷を帯びたサイトが存在す るか，またはイオンの吸着により界面が電荷を帯び，界 面近傍に電気二重層が形成される。このような層をイオ ンが通過する場合, イオンは静電場の影響を受け, イオ ンの動的挙動は変化する。固一液界面に静電場が存在し ている場合の速度論的取扱いについて, 単純な反応であ る負に荷電した吸着サイト $\mathrm{S}^{-}$への陽イオン $\mathrm{M}^{+}$の吸脱 着反応について述べる。

$$
\mathrm{S}^{-}+\mathrm{M}^{+} \underset{k_{\mathrm{d}}}{\frac{k_{\mathrm{a}}}{\mathrm{S}}} \mathrm{SM}
$$

ここで $k_{\mathrm{a}}$ 打よび $k_{\mathrm{d}}$ 注それぞれ吸着打よび脱着速度定 数を表わす。この反応の平衡定数 $K$ は次式で与えられ る3)。

$$
\begin{aligned}
K & =\frac{[\mathrm{SM}]}{\left[\mathrm{S}^{-}\right]\left[\mathrm{M}^{+}\right]}=\frac{[\mathrm{SM}]}{\left[\mathrm{S}^{-}\right]\left[\mathrm{M}^{+}\right]_{s} \exp \left(\frac{e \bar{\Psi}_{\beta}}{k T}\right)} \\
& =K^{\text {int }} \exp \left(-\frac{e \bar{\Psi}_{\beta}}{k T}\right)
\end{aligned}
$$

ここで

$$
\bar{\Psi}_{\beta}=\zeta+\frac{11.74 V \bar{I}}{C_{2}} \sinh \left(\frac{e \zeta}{2 k T}\right)
$$

上式の下付き $\mathrm{s}$ および上付きint はそれぞれ表面および 固有を意味し，らおよび $\bar{\Psi}_{\beta}$ はそれぞれゼー夕電位およ び Davis 引により定義された $\beta$ 面における電位 ${ }^{32}, C_{2}$ は $\beta$ 面における静電容量, および $I$ はイオン強度を表 わす。（2）式において $\mathrm{H}^{+}$のような電位決定イオンの場 合には $\bar{\Psi}_{\beta}$ 電位よりむしろ表面電位 $\bar{\Psi}_{0}\left(\left|\bar{\Psi}_{0}\right|>\left|\bar{\Psi}_{\beta}\right|\right)$ を 
用いる。平衡定数之同様に, 吸着および脱着速度定数む また $\bar{\Psi}_{\beta}$ 電位の影響を受け, 著者らにより, 次式が導び かれだ)。

$$
\begin{aligned}
& k_{\mathrm{a}}=k_{\mathrm{a}}{ }^{\mathrm{int}} \exp \left(-\frac{e \bar{\Psi}_{\beta}}{2 k T}\right) \\
& k_{\mathrm{d}}=k_{\mathrm{d}}{ }^{\mathrm{int}} \exp \left(\frac{e \bar{\Psi}_{\beta}}{2 k T}\right)
\end{aligned}
$$

てれらの式からわかるように， $\bar{\Psi}_{\beta}$ 電位が負になるにし たがい吸着速度定数は加速され, 逆に脱着速度定数は減 速される。

\section{3 固-液界面における動的酸・塩基特性}

金属酸化物表面には表面水酸基 $\mathrm{SOH}$ が存在し，次の ような両性的特性を示す3)。

$$
\begin{aligned}
& \mathrm{SOH}_{2}+\underset{k_{\mathrm{a}}}{\stackrel{k_{\mathrm{d}}}{\longrightarrow}} \mathrm{SOH}+\mathrm{H}^{+} \\
& \mathrm{SOH} \longrightarrow \mathrm{SO}^{-}+\mathrm{H}^{+}
\end{aligned}
$$

さらに, $\mathrm{SOH}_{2}{ }^{+}$および $\mathrm{SO}^{-}$はそれぞれ対イオン $\mathrm{B}^{-}$お よび $\mathrm{A}^{+}$とイオン対を形成し, 次の反応が起てる。

$$
\begin{gathered}
\mathrm{SOH}_{2}{ }^{+}+\mathrm{B}^{-} \longrightarrow \mathrm{SOH}_{2}{ }^{+}-\mathrm{B}^{-} \\
\mathrm{SO}^{-}+\mathrm{A}^{+} \longrightarrow \mathrm{SO}^{-}-\mathrm{A}^{+}
\end{gathered}
$$

反応 $(5)$ の例として, $\mathrm{Fe}_{2} \mathrm{O}_{3}$ および $\mathrm{Fe}_{3} \mathrm{O}_{4}$ 微粒子けん 濁液系で観測された緩和時間 $\tau$ の $\mathrm{pH}$ 依存性は Fig. 4 に示すように極小を持ち5)，その緩和時間は次式で与え

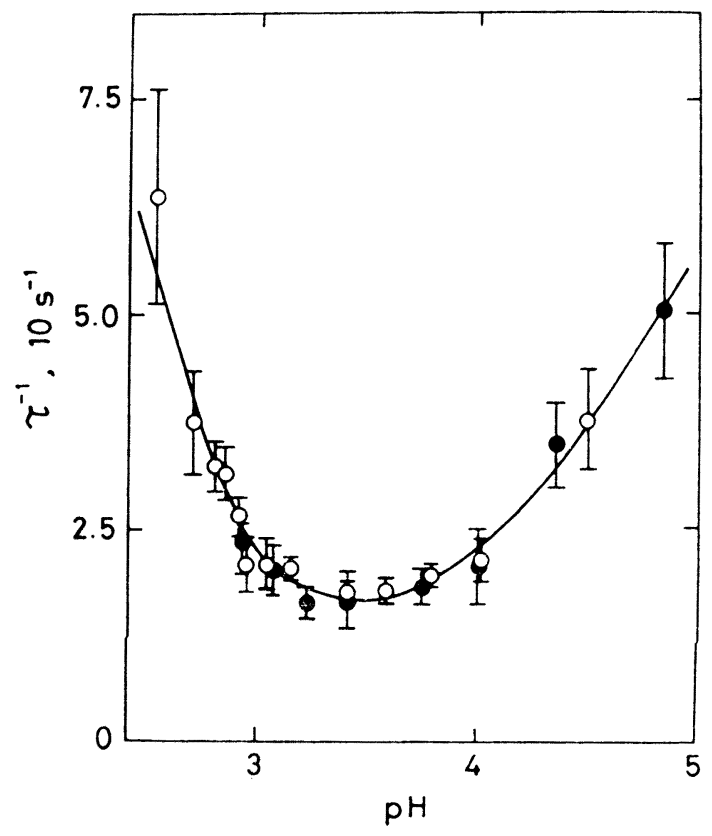

Fig. $4 \mathrm{pH}$ dependence of the reciprocal relaxation time $\tau^{-1}$ obtained in the acidic hematite $(O)$ and magnetite $(\mathbf{O})$ aqueous suspensions at $25^{\circ} \mathrm{C}$. The solid line is a best-fit parabolic curve for the data ${ }^{5}$.
られる。

$$
\begin{aligned}
\tau^{-1}= & k_{\mathrm{a}}{ }^{\text {int }} \exp \left(-\frac{e \bar{\Psi}_{0}}{2 k T}\right)\left([\mathrm{FeOH}]+\left[\mathrm{H}^{+}\right]\right) \\
& +k_{\mathrm{d}}{ }^{\text {int }} \exp \left(\frac{e \bar{\Psi}_{0}}{2 k T}\right) \frac{K_{\text {anion }}+\left[\mathrm{FeOH}_{2}{ }^{+}\right]}{K_{\text {anion }}+\left[\mathrm{FeOH}_{2}{ }^{+}\right]+\left[\mathrm{B}^{-}\right]}
\end{aligned}
$$

ここで $K_{\text {anion }}$ は反応 $(7)$ の平衡定数であり, 緩和時間 は非常に速い反応 $(7)$ がカップルしている。ての式によ り解析した結果, 緩和時間 $\tau$ の理論曲線は Fig. 4 の実 線で示すように実験值とよく一致し, 速度定数 $k_{\mathrm{a}}{ }^{\mathrm{int}}$ お よび $k_{\mathrm{d}}^{\text {int }}$ が得られる。圧力ジャンプ法による, 種々の 固体の表面に存在する固体酸についての一連の速度論的 研究から, 固体酸性度 $K_{\mathrm{a}}$ と酸解離速度定数 $k_{\mathrm{d}}{ }^{\mathrm{int}}$ およ び会合速度定数 $k_{\mathrm{a}}{ }^{\text {int }}$ との間に Fig. 5 に示すような興 味ある関係が存在する $2.5-8$ 。すすねわ $\mathrm{Fe}_{2} \mathrm{O}_{3}$ や $\mathrm{TiO}_{2}$ のような通常の固体酸の場合は, $k_{\mathrm{d}}{ }^{\mathrm{int}}$ は $K_{\mathrm{a}}$ に比例し, $k_{\mathrm{a}}{ }^{\text {int }}$ はほとんど $K_{\mathrm{a}}$ に依存しないが, 強い固体酸, 例え ば,シリカアルミナ・ $\gamma$ 型のリン酸ジルコニウム等の場 合は $k_{\mathrm{a}}{ }^{\mathrm{int}}$ および $k_{\mathrm{d}}{ }^{\mathrm{int}}$ はいずれあてれらの傾向からはず れる。さらに, Diethylaminoethyl (DEAE) 基のよう な陰イオン交換樹脂の場合は, 樹脂の三次元網目構造の ために $k_{\mathrm{a}}^{\mathrm{int}}$ のみが小さな值を示す。

反応 $(7)$ および (8) はイオンとサイト間の相互作用が 反応 $(5)$ および (6)の場合に比べかなり弱いととから, 非常に速い反応と予想され，電場パルス法により，乙れ

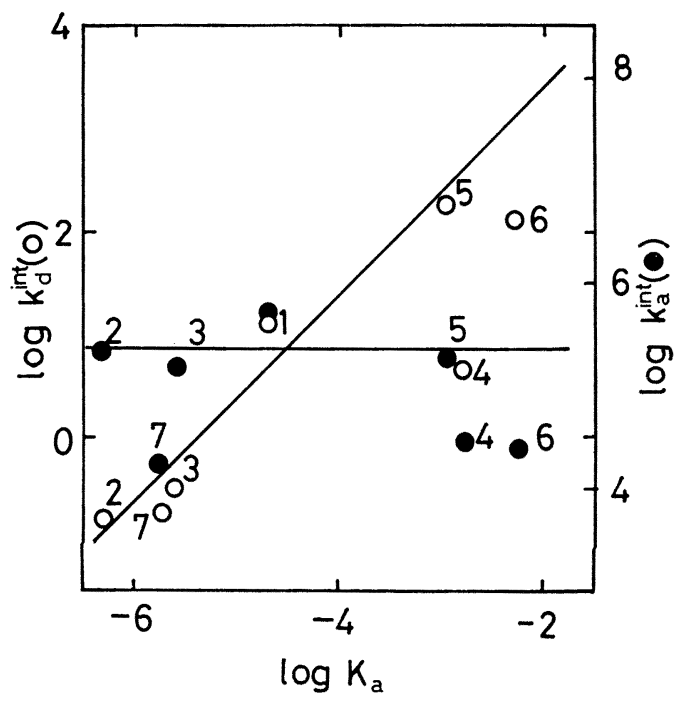

Fig. 5 Relationship between $k_{\mathrm{a}}{ }^{\text {int }}(O)$ and $k_{\mathrm{d}}{ }^{\text {int }}$ (O) and intrinsic acidity constant $K_{\mathrm{a}}{ }^{\text {int }}:$ (1) $\mathrm{TiO}_{2}$ (ref.2), (2) $\mathrm{Fe}_{2} \mathrm{O}_{3}$ (ref. 5), (3) $\mathrm{Fe}_{3} \mathrm{O}_{4}$ (ref. 5), (4) silicaalumina (ref. 6), (5) $\alpha$ zirconium phosphate (ref. 7), (6) $\gamma$-zirconium phosphate (ref. 7), (7) DEAE group (ref. 8). 


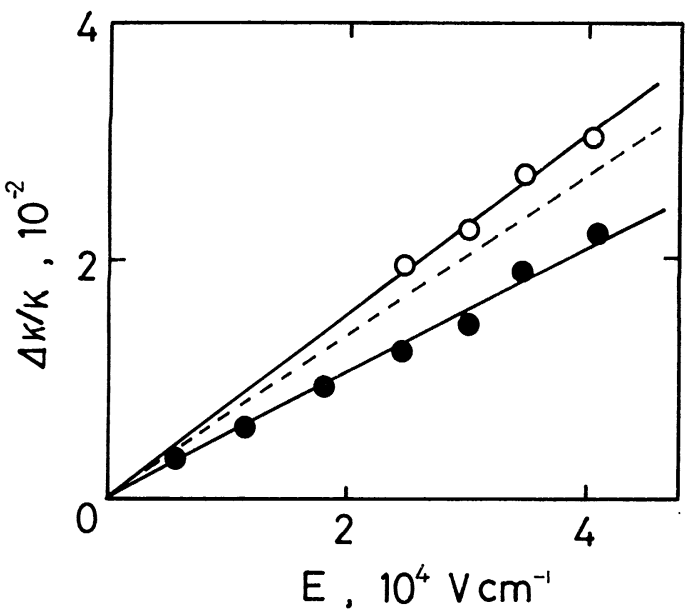

Fig. 6 Electric field intensity dependences of the relaxation amplitude in $\alpha-\mathrm{FeOOH}-\mathrm{HClO}_{4}$ (O) and $\alpha-\mathrm{FeOOH}-\mathrm{HCl}$ (O) systems. The dashed line shows the theoretical straight line evaluated by Onsager's theory for dissociation field effect ${ }^{4,9)}$.

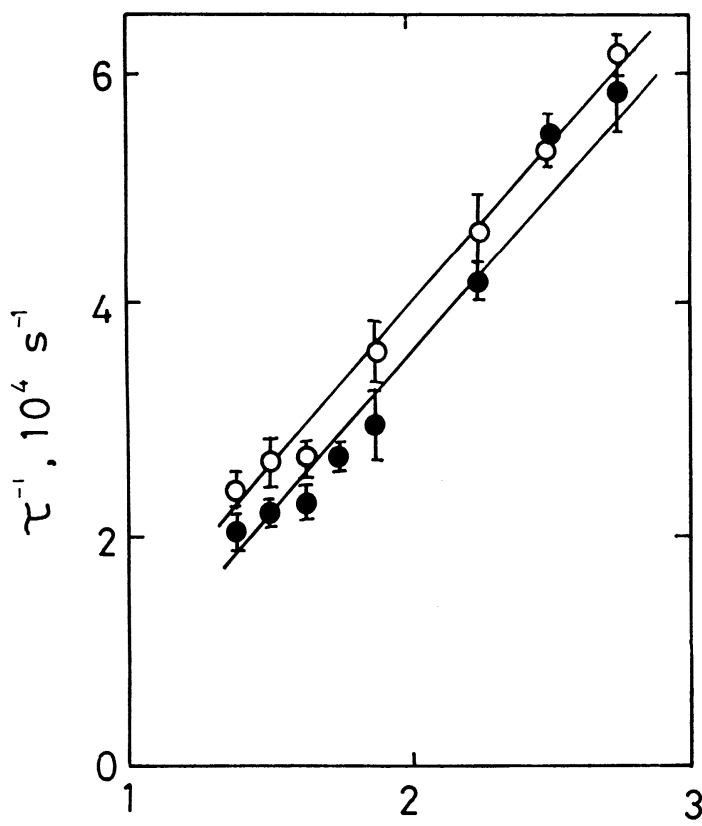

[B], $10^{-3} \mathrm{~mol} \mathrm{dm}^{-3}$

Fig. 7 Plots of the reciprocal relaxation time vs. the initial concentration of anion in $\alpha-\mathrm{FeOOH}-$ $\mathrm{HClO}_{4}(\mathrm{O})$ and $\alpha-\mathrm{FeOOH}-\mathrm{HCl}(\mathrm{O})$ systems ${ }^{4}$.

らの反応に基づく緩和が観測されだ)。 $\mathrm{FeOOH}$ 酸性け ん濁液において得られた緩和強度 $\Delta \kappa / \kappa(\kappa$ は電導度を 表わす）の電場強度 $E$ 依存性を Fig. 6 亿示す。 $\Delta \kappa / \kappa$ の值は $E$ に比例し, その依存性は解離場効果に関する

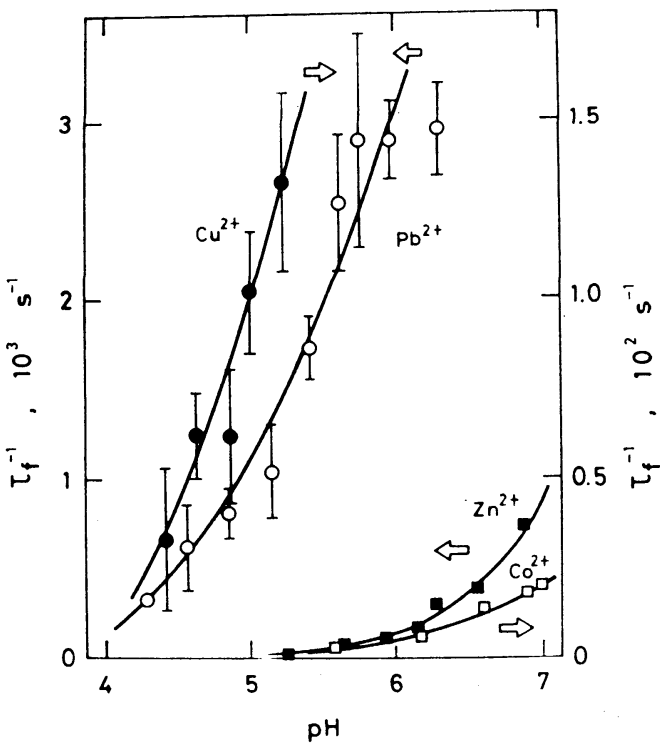

Fig. $8 \mathrm{pH}$ dependences of $\tau_{\mathrm{f}}^{-1}$ in the aqueous $\gamma-\mathrm{Al}_{2} \mathrm{O}_{3}$ and metal nitrate suspensions of $\left[\mathrm{M}^{2+}\right]$ $=3 \times 10^{-3} \mathrm{~mol} \mathrm{dm}^{-3}$. The solid curves are theoretical ones estimated ${ }^{11)}$.

Onsager の理論と一致している ${ }^{9)}$ 。

$$
\frac{\Delta \kappa}{\kappa}=\frac{(1-\alpha)\left|u_{1}-u_{2}\right|}{(2-\alpha)\left(u_{1}+u_{2}\right)} \cdot \frac{e^{3}}{8 \pi \epsilon_{0} \epsilon(k T)^{2}} E
$$

ここで $\alpha$ は解離度， $u$ は易動度を表わす。このように不 均一系でも Onsager の解離場効果の理論は成り立つ。 得られた緩和時間の対イオン濃度依存性を Fig. 7 に示 す。 $\tau^{-1}$ は対イオン濃度に大きく依存し, 解析の結果, これらの依存性は反応機構 (7)ではなく, 次のような反 応機構でのみ説明できる。

$$
\begin{aligned}
& \mathrm{B}^{-}+\text {surface } \underset{\text { (very fast diffusion process) }}{\longrightarrow} \mathrm{B}_{\beta}^{-} \\
& \mathrm{B}_{\beta}{ }^{-}+\mathrm{SOH}_{2}{ }^{+} \longrightarrow \mathrm{SOH}_{2}{ }^{+}-\mathrm{B}^{-}
\end{aligned}
$$

すなわち，対イオンはバルク相から $\beta$ 面まで拡散し，表 面を二次元昖散しながらサイトである $\mathrm{SOH}_{2}{ }^{+}$に接近し てイオン対を形成する。てのような詳細な反応機構は静 的には明らかにするととは出来ず，不均一系速度論によ るところ大である。

\section{4 金属酸化物表面への重金属イオン $\mathbf{M}^{2+}$ の特異吸} 着

重金属イオンが金属酸化物表面に特異的によく吸着さ れるととは古くから知られており，様々な反応機構が提 唱されているが，いまだ不明な点が多い。著者らは $\gamma$ アルミナけん濁液に種々の重金属イオンを添加した系に おいて，圧力ジャンプ法により，二重緩和を見い出し た ${ }^{10.11)}$ 。得られた速い緩和時間の $\mathrm{pH}$ 依存性を Fig. 8 に示す。遅い緩和の場合む全く同様な $\mathrm{pH}$ 依存性を示 


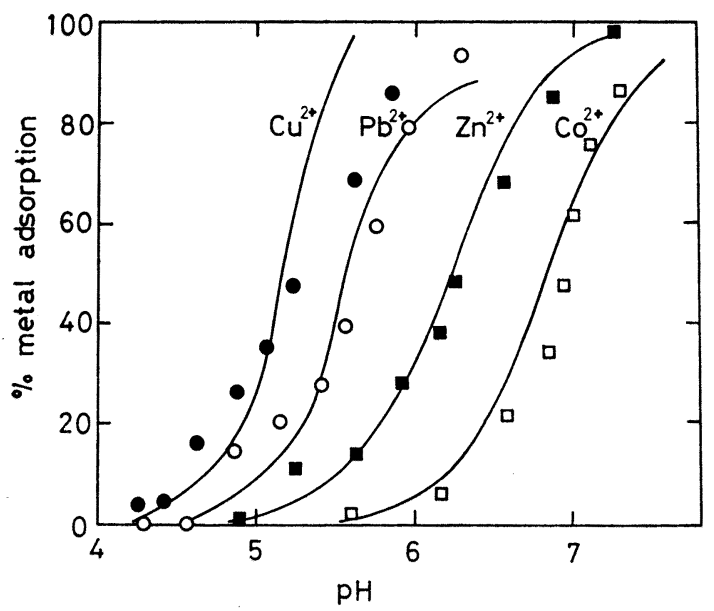

Fig. $9 \mathrm{pH}$ dependences of $\%$ adsorption of divalent metal ions to $\gamma-\mathrm{Al}_{2} \mathrm{O}_{3}$. The solid curves are the theoretical ones on the basis of the coordinate adsorption model ${ }^{10)}$.

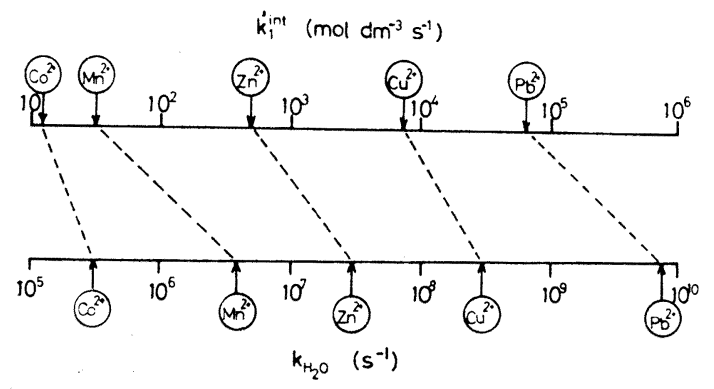

Fig. 10 Relationship between $k_{1}^{\text {int }}$ and the rate constants for a release of water molecule from hydrated metal ion in the metal complex formation, $k_{\mathrm{H}_{2}} \mathrm{O}$, for the divalent metal ions ${ }^{11)}$.

しとこことは吸着エネルギーの異なる数種のサイトの 存在を示唆している。一方, \% 吸着量の $\mathrm{pH}$ 依存性は Fig. 9 亿示すように, 加水分解しやすい重金属イオン ほど低 $\mathrm{pH}$ 領域で吸着する傾向がある。しかしながら， $\tau^{-1}$ の $\mathrm{pH}$ 依存性にはそのような傾向は見い出せなノ

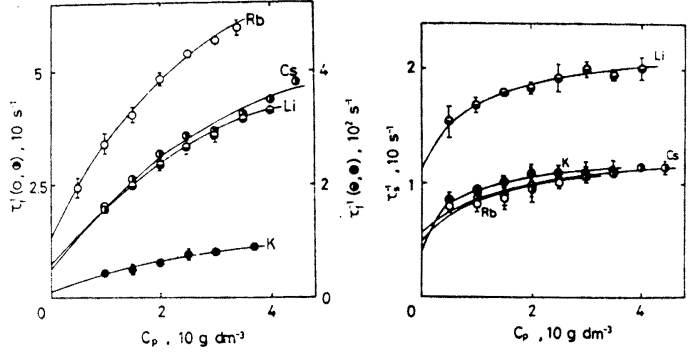

Fig. 11 Particle concentration dependences of the fast and slow relaxation times obtained in the aqueous suspensions of $\mathrm{TiS}_{2}(\mathrm{M})$ at $25^{\circ} \mathrm{C}^{13}$.

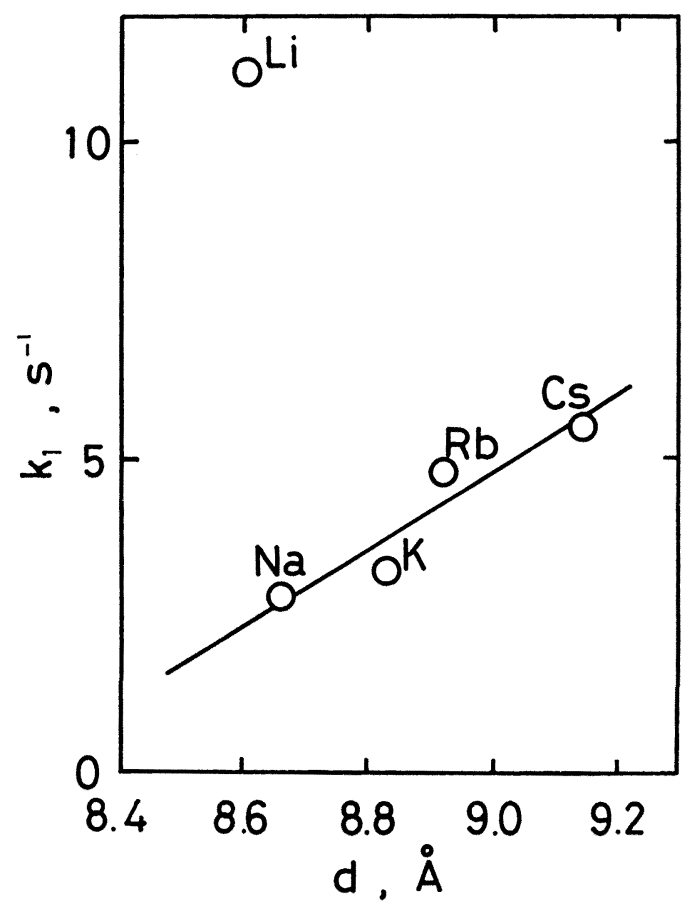

Fig. 12 Relationship between $k_{1}$ and $d^{13)}$.

フい。このような違いは次の反応機構によって明らかに される。

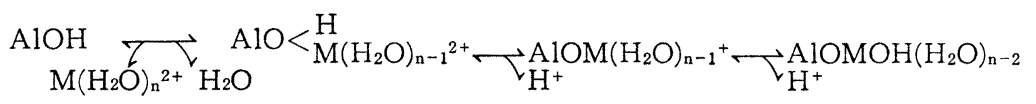

ての反応機構からわかるように，全反応過程比金属酸化 物表面で起る吸着した金属イオンの加水分解反応であ る。しかしながら，観測された速い緩和は反応機構 (12) の第 1 過程である金属イオンからの水分子脱離を伴なう 吸脱着反応に基づくものであり, 得られた吸着速度定数 は Fig. 10 亿示すように，均一系における金属イオン 加らの水分子脱離の速度定数とよく対応している。この
ように, 速度論的研究が不均一系で起る現象の理解に大 いに役立つ。

1.5 層状化合物への陽イオン・インターカレーション 層状化合物はその層間に陽イオンおよびドナーをゲス トとしてインターカレートさせ，インターカレートによ りその化合物の物性が著しく変化し, 吸着剂の他に触媒 や固体電解質として応用性の面から注目されている。と 
くに Li をインターカレートした $\mathrm{TiS}_{2}$ は高性能なリチ ウム電池の材料として有望視されている。压力ジャンプ 法により, 種々のアルカリ金属イオンをインターカレー 卜した $\mathrm{TiS}_{2}$ けん濁液において二重緩和を見い出し, 得 られた速い緩和および遅い楥和の緩和時間は Fig. 11 に示すような粒子濃度依存性を示す ${ }^{12,13)}$ 。得られた結果 は次のようなインターカレーション・デインターカレー ション機構に帰属される。

$$
\left(\mathrm{TiS}_{2}(\mathrm{M})\right)_{i} \frac{k_{1}}{k_{-1}}\left(\mathrm{TiS}_{2}(\mathrm{M})\right)_{\mathrm{s}} \underset{\text { (slow process) }}{\stackrel{k_{2}}{k-2} \mathrm{M}^{+}} \mathrm{TiS}_{2}^{-}
$$

こてで下付き $\mathrm{i}$ は層間を意味し， $\mathrm{TiS}_{2}-$ はアルカリ金属 イオンが脱離したサイトを表わす。得られたデインター カレーション速度定数 $k_{1}$ の層間距離 $\mathrm{d}$ 依存性は Fig.12 に示すように, $\mathrm{Li}^{+}$の場合が他のアルカリ金属イオンの 場合に比べ 1 析大きい。乙のととは Li がインターカレ 一トした $\mathrm{TiS}_{2}$ は他のものと異なり, イオン導電体であ ることを示唆している。

上述の系の他，ゼオライト細孔内でのアルカリ金属イ オンおよびアミンと細孔内の $\mathrm{Na}^{+}$とのイオン交换反応 速度定数が細孔容積に著しく依存するとと ${ }^{14,15)}$, シク口 デキストリンポリマーと陰イオンとの包接反応の速度定 数はシクロデキストリンモノマーの場合に比べ著しく異 なることなど ${ }^{6)}$, 固一液界面における様々な高速反応の 機構が圧力ジャンプ法な電場パルス法で解明され, 数多 くの興味ある知見が得られている。

\section{2. 表面波法および気一液界面反応への応用}

Kelvin 卿は池のさざ波をステッキに仕組んだ油によ り消して民衆を警かしたという有名な話がある。とのよ うに，様々な分子が水面に存在すれば，さざ波の減衰が

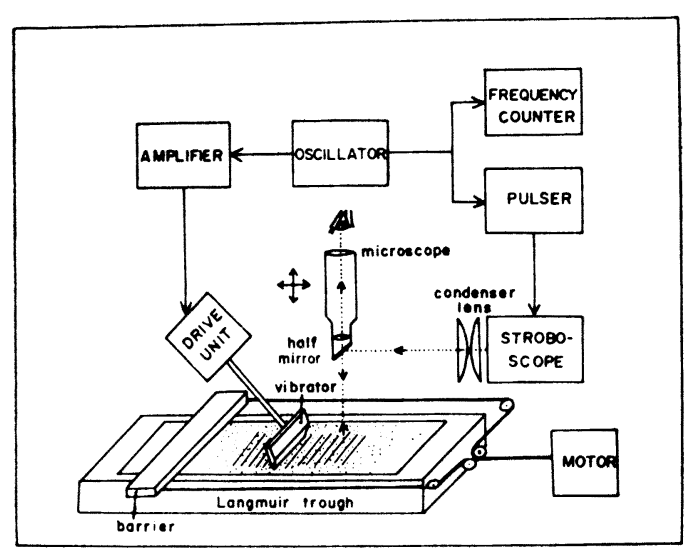

Fig. 13 Block diagram of the apparatus for measurements of the propagation characteristics of the capillary wave ${ }^{18}$.
著しく増大する。すし，さざ波を自由に制御出来孔ば， 波の伝播特性（伝播速度 $C$ および減衰係数 $\alpha$ ) から気一 液界面の動的情報が得られるであろう。このような観点

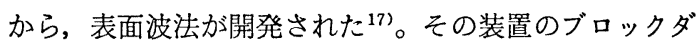
イヤグラムを Fig. 13 亿示す。振動子により気-液界面 に生じた平行表面波をその周波数と同期したストロボ光 で照明すると，表面波の静止像を得る。これを顕微鏡で 観測すると，表面波の山または谷の部分からのストロボ 光の反射によるシャープな焦点像が見える。その像間距 離および焦点距離の減衰からそれぞれ伝播速度および減 衰係数が得られる。Cおよび $\alpha$ は水面ではそれぞれ次 式で与えられる。

$$
\begin{aligned}
& \frac{C^{3}}{f}-\frac{g \lambda^{2}}{2 \pi}=\frac{2 \pi \gamma}{\rho}=\text { 一定 } \\
& \frac{\alpha}{f}=\frac{8 \pi \rho \nu}{3 \gamma}=\text { 一定 }
\end{aligned}
$$

ここで $g$ は重力加速度, $\gamma$ は表面張力を表わす。界面活 性剤水溶液表面や水面に単分子膜を展開した系では $C$ に 分散および $\alpha$ に吸収が現われる。とくに後者の場合は 顕著である。乙の場合， $\alpha$ は表面熱力学および二次元緩 和理論に基づいて次式で与えられる ${ }^{18)}$ 。

$$
\begin{aligned}
& \frac{\alpha}{f}=\frac{\alpha_{\mathrm{d}}}{f}+\frac{2 \pi \gamma k}{3 \rho C^{3}} \cdot \frac{\omega^{\prime} \tau \delta^{\prime}}{1+\omega^{\prime 2} \tau^{2}}\left(\omega^{\prime}=2 \omega\right) \quad \text { または } \\
& \frac{3 \rho C^{3}}{2 \pi \gamma k}\left(\frac{\alpha}{f}-\frac{\alpha_{\mathrm{d}}}{f}\right)=\frac{\omega^{\prime} \tau \delta^{\prime}}{1+\omega^{\prime 2} \tau^{2}}
\end{aligned}
$$

ここで $\alpha_{\mathrm{d}}$ はバルク相と気一液界面との間のイオンの拡 散汇基づく $\alpha$ であり， $\omega$ は表面波の角振動数， $\delta^{\prime}$ は緩 和強度を表わす。表面波法により, 種々の界面活性剂水 溶液表面における $\alpha$ の周波数依存性を Fig. 14 亿示す。

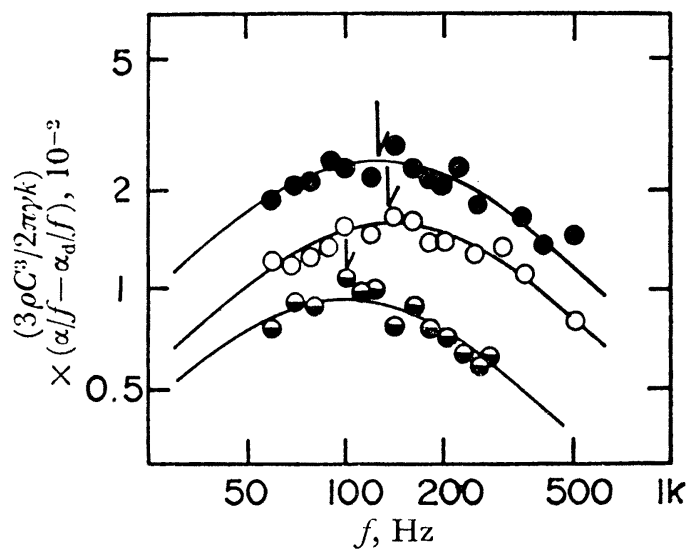

Fig. 14 The plots of $\left(3 \rho c^{3} / 2 \pi \gamma k\right) \cdot\left(\alpha / f-\alpha_{\mathrm{d}} / f\right)$ vs. $f$ in $8 \times 10^{-3} \mathrm{~mol} \mathrm{dm}^{-3} \mathrm{SDS},(\bigcirc), 1.5 \times 10^{-2}$ $\mathrm{mol} \mathrm{dm}{ }^{-3} \mathrm{DAC}(\mathbf{O})$, and $1.21 \times 10^{-1} \mathrm{~mol} \mathrm{dm}^{-3}$ OAC (-) solutions. The solid lines show the theoretical curves calculated ${ }^{19}$. 


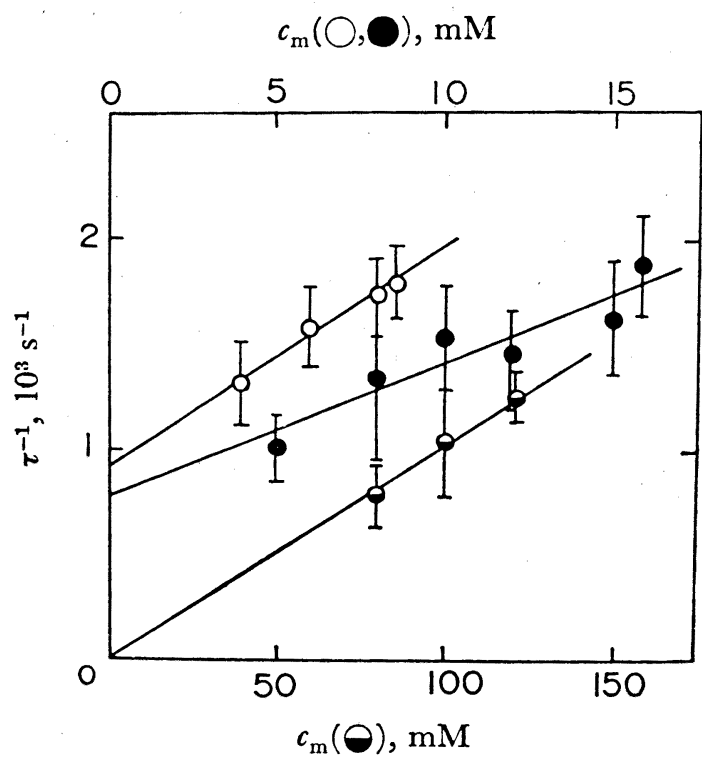

Fig. 15 The plots of $\tau^{-1}$ vs. $c_{\mathrm{m}}$ in $\operatorname{SDS}(\bigcirc)$,

$\operatorname{DAC}(\mathbf{O})$, and OAC (I) solutions ${ }^{19}$.

実験結果は実線で示される理論曲線によくのっており, これらの曲線のピークにおける周波数と強度からそれぞ れ $\tau$ および $\delta^{\prime}$ の值を得る。得られた緩和時間は Fig. 15 に示すように界面活性剤濃度 $C_{\mathrm{m}}$ に依存しており, 解 析の結果, 緩和は次の反応機構に帰属された。

$$
\mathrm{S}_{\mathrm{s}} \underset{\begin{array}{c}
k_{\mathrm{d}} \\
\text { adsorption-desorption } \\
\text { process }
\end{array}}{\stackrel{k_{\mathrm{a}}}{\text { (diffusion process) }}} \mathrm{S}_{\text {sub }} \longrightarrow \mathrm{S}_{\mathrm{b}}
$$

ことで S は界面活性剤分子を表わし，下付き sub および bはそれぞれ表面近傍の sub 相およびバルク相を意味す る。得られた吸着速度は HLB (hydrophile liophile

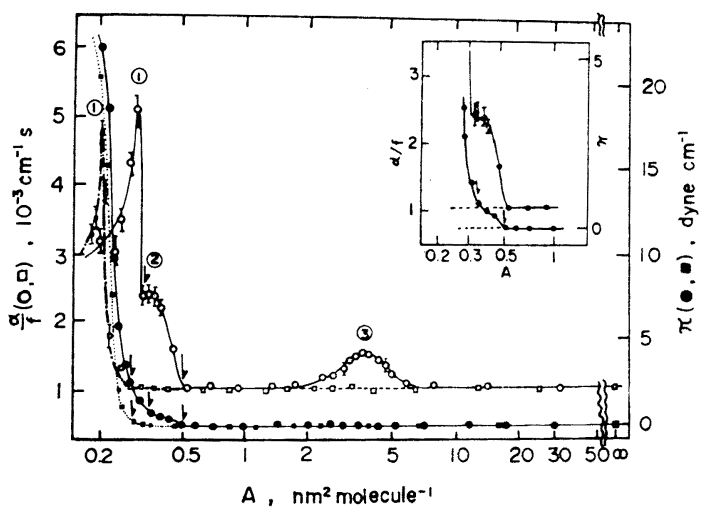

Fig. 16 The changes in $\alpha / f$ and $\pi$ with $A$ on the stearic acid monolayer spread on the clean water (squares) and on $1.0 \times 10^{-5} \mathrm{~mol} \mathrm{dm}^{-3} \mathrm{SDS}$ solution $(\text { circles })^{20)}$. balance) 值と次のような関係にある ${ }^{19)}$ 。

$$
\log k_{\mathrm{a}}=0.25 \mathrm{HLB}+1.8
$$

HLB 值は界面活性剂の特性を評価するのに用いられ る指数であり，乙の関係はその特性が吸着速度定数と密 接に関係していることを示すものとして興味深い。さら に, $\delta^{\prime}$ の濃度依存性加ら, 標準モル表面張力变化も得 られる。

では, 水や水溶液表面に不溶性単分子膜を展開した場 合はどうであろうか。SDS のような界面活性剤水溶液 にステアリン酸やアラキジン酸等の単分子膜を展開した 表面における $\alpha / f$ は Fig. 16 に示すように, 表面压 $\pi$ の分子表面積 $A$ 依存性に現われる二次元転移点で起る $\alpha / f$ の異常性(1)およ゙(2)以外に， $\pi$ お 曲線では何ら異 常が見い出せない領域で $\alpha / f$ の值が水の值よりも大き くなる現象(3)が見い出された ${ }^{20)}$ 。前者にはまだ理論的基 礎が確立されていないが, 後者は著者らが導びいた二次 元緩和理論で説明でき, 解析の結果, 次のようなステア リン酸二次元ミセルと吸着した SDS 分子との会合体形 成反応機構に帰属された。

$$
\left(\mathrm{S}_{1}\right) \hat{n} \longrightarrow \underset{\mathrm{S}_{2}}{\longrightarrow}\left(\mathrm{S}_{1}\right) \hat{n}-2
$$

ここで $\left(S_{1}\right) \hat{n}$ および $\left(S_{1}\right) \hat{n}-2$ はステアリン酸二次元ミセ ル， $\mathrm{S}_{2}$ および $\mathrm{S}^{*}$ はそれぞれ SDS 分子および会合体を 表わす。とのように，気一液界面に反応が存在すれば， 表面波法により反応に関する動的知見が得られる。さら に, この方法は二次元相転移現象の解明に有力な手段之 なりうる。

\section{3. 気体濃度ジャンプ法および気一固界面反応 への応用}

固体表面での触媒反応, 競争吸着による分離等は応用

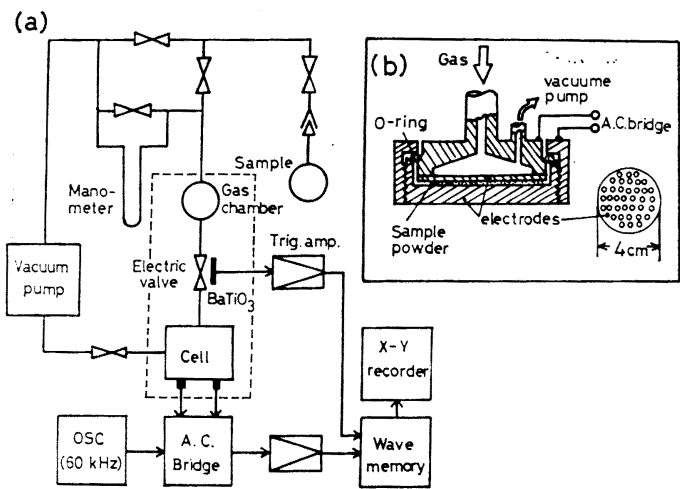

Fig. 17 Block diagram (a) of the gas concentration-jump apparatus and the cross section of the cell $(b)^{21)}$. 

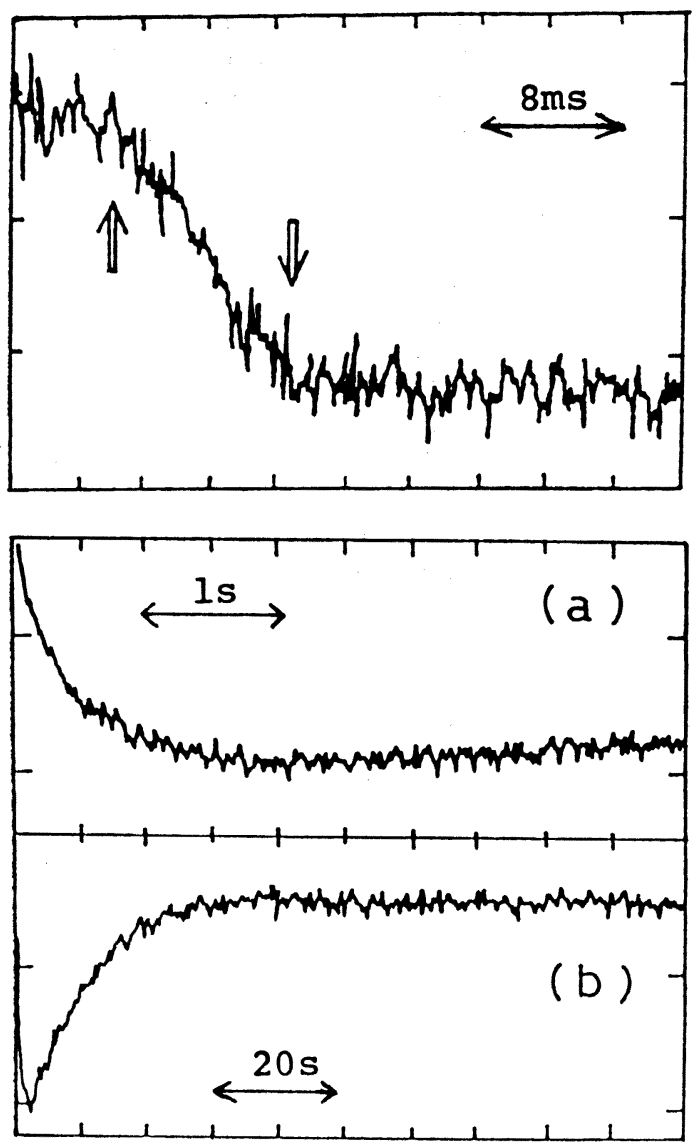

Fig. 18 The signal obtained in $\mathrm{TiO}_{2}-\mathrm{H}_{2}$ system and the relaxation curves obtained in $\mathrm{H}-\mathrm{ZSM}$ $5-\mathrm{CH}_{3} \mathrm{OH}$ system using the gas concentrationjump technique ${ }^{21)}$.

的に極めて重要であるが, まだ科学的触媒設計という段 階に至っておらず，反応機構の詳細を解明するためには 動的研究が必要不可欠である。そのためには, Fig. 17 のブロックダィヤグラムに示すような気体濃度ジャンプ 法は有効である ${ }^{211}$ 。図のように, 試料粉末を電極間には さみ, 真空容器に入れ, この容器とガス容器とを真空電 磁弁で連結する。試料容器を真空またはガス容器よりあ 低圧にした後, 電磁弁を開くと, Fig. 18 に示すよう に， 1 番目の矢印までの時間，すなわち約 10 ミリ秒（1 $\mathrm{mm}$ 厚の試料の場合) 以内に気体の注入が完了する。そ の後 2 番目の矢印までの過程は試料粉体への気体の吸着 および反応過程を電導度または静電容量の時間変化とし て観測したあのである。本装置により測定されたメタノ 一ルからガソリン合成の触媒として注目されている $\mathrm{H}-$ ZSM-5 とメタノールと反応に基づく二重緩和を Fig. 18 に示す（ただし，ここではメタノールの吸着に伴なう測

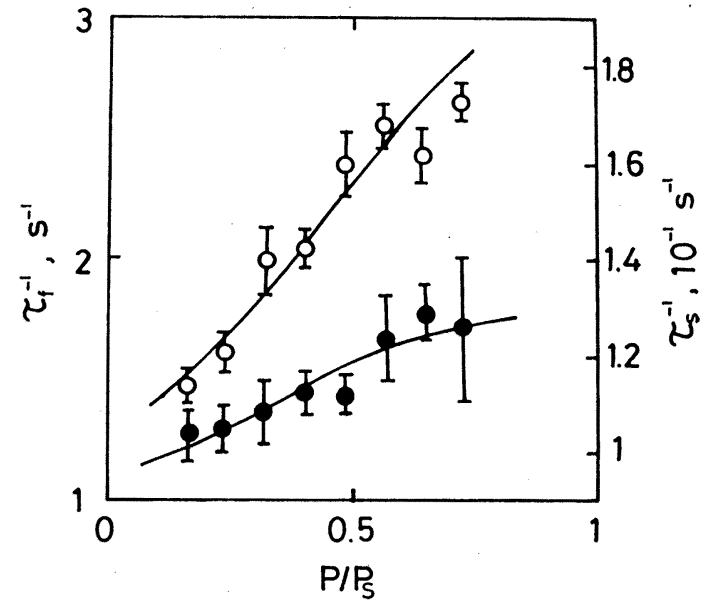

Fig. 19 Methanol pressure dependences of the fast $(\bigcirc)$ and slow (O) relaxation times ${ }^{21}$.

定限界内の極めて速い反応は存在しないので Fig. 1 (a)のようなステップ状の変化は観測されない)。得ら れた緩和時間は Fig. 19 に示すように，速い緩和の場 合ではかなりメタノール死力依存性を示すが，遅い緩和 の場合には圧力依存性は小さい。解析の結果, H-ZSM5 のトンネル内に存在する固体酸サイトへのメタノール 共吸着機構が提唱された。

$$
\mathrm{CH}_{3} \mathrm{OH}(\mathrm{g}) \longrightarrow \underset{\text { (fast process) (slow process) }}{\mathrm{S}} \longrightarrow \mathrm{CH} \mathrm{CH}_{3} \mathrm{OH}(\mathrm{int}) \underset{\mathrm{C}}{\mathrm{C}} \longrightarrow \mathrm{C}^{*}
$$

および

$$
\mathrm{CH}_{3} \mathrm{OH}(\mathrm{g}) \underset{\mathrm{SOH}}{\mathrm{H}_{\mathrm{H}} \mathrm{O}}
$$

ここでSは H-ZSM-5 のトンネル内の強い固体酸とメ タノールとの反応によりメトキシ化したサイトを表わ し，C および C* はそれぞれメトキシ化したサイトに 共吸着した状態およびその形態変化を表わす。反応機構 (20)は最終生成物である C* とサイト間の結合が切れる ことにより, ジメチルエーテルの生成と強い固体酸サイ ト SOH の再生の可能性を示唆しており, 気体濃度ジャ ンプ法により, 高温で H-ZSM-5 のトンネル内でメタ ノールからジメチルエーテルを経てガソリンが生成され る反応の初期過程に関する重要な知見が得られた。予備 的ではあるが，本方法により，種々の緩和を見い出して おり，その応用範囲も広く有効な手段となり得るである う。

\section{4. おわりに}

著者らが開発した不均一系高速反応の速度論の研究成 果は最近世界で注目され始めてきており,さらに様々な 系への適用が可能であり，また種々の新しい方法の開発 
あ必要であろう。特に気体濃度ジャンプ法は触媒反応の 動的解明という観点からその適用性は大であろう。

\section{文献}

1) K. Hachiya, M. Ashida, M. Sasaki, T. Inoue and T. Yasunaga: J. Phys. Chem. 83 (1979) 1866.

2) M. Ashida, M. Sasaki, H. Kan, T. Yasunaga, K. Hachiya and T. Inoue : J. Colloid Interface Sci. 67 (1978) 219.

3) J. A. Davis, R. O. James and J. O. Leckie: J. Colloid Interface Sci. 63 (1978) 480.

4) M. Sasaki, M. Moriya, T. Yasunaga and R. D. Astumian: J. Phys. Chem. 87 (1983) 1449.

5) R.D. Astumian, M. Sasaki, T. Yasunaga and Z. A. Schelly: J. Phys. Chem. 85 (1981) 3832.

6) T. Ikeda, M. Sasaki, K. Hachiya, R. D. Astumian and T. Yasunaga: J. Phys. Chem. 86 (1982) 3861.

7) M. Sasaki, N. Mikami, T. Ikeda, K. Hachiya and T. Yasunaga: J. Phys. Chem. 86 (1982) 5230.

8) K. Hachiya, M. Sasaki, Y. Nabeshima, N. Mikami and T. Yasunaga: J. Phys. Chem. 88 (1984) 1623.
9) L. Onsager: J. Phys. Chem. 2 (1934) 599.

10) K. Hachiya, M. Sasaki, Y. Saruta, N. Mikami and T. Yasunaga: J. Phys. Chem. 88 (1984) 23.

11) K. Hachiya, M. Sasaki, T. Ikeda, N. Mikami and T. Yasunaga: J. Phys. Chem. 88 (1984) 27.

12) H. Negishi, M. Sasaki, T. Yasunaga and $M$. Inoue: J. Phys. Chem. 88 (1984) 1455.

13) M. Sasaki, H. Negishi, H. Ohuchi, M. Inoue and T. Yasunaga: J. Phys. Chem. (submitted).

14) T. Ikeda, M. Sasaki and T. Yasunaga : J. Phys. Chem. 87 (1983) 745.

15) T. Ikeda, J. Nakahara, M. Sasaki and T. Yasunaga: J. Colloid Interface Sci. 97 (1984) 278.

16) M. Sasaki, T. Ikeda, N. Mikami and T. Yasunaga: J. Phys. Chem. 87 (1983) 5.

17) M. Sasaki, T. Yasunaga and N. Tatsumoto: Bull. Chem. Soc. Jpn. 50 (1977) 858.

18) M. Sasaki, T. Yasunaga and N. Tatsumoto: Bull. Chem. Soc. Jpn. 50 (1977) 852.

19) M. Sasaki, T. Yasunaga, S. Satake and M. Ashida: Bull. Chem. Soc. Jpn. 50 (1977) 3144.

20) M. Sasaki : J. Sci. Hiroshima Univ. Ser. A 41 (1977) 195.

21) H. Negishi, M. Sasaki, T. Iwaki, K. F. Hayes and T. Yasunaga: J. Phys. Chem. (in press).

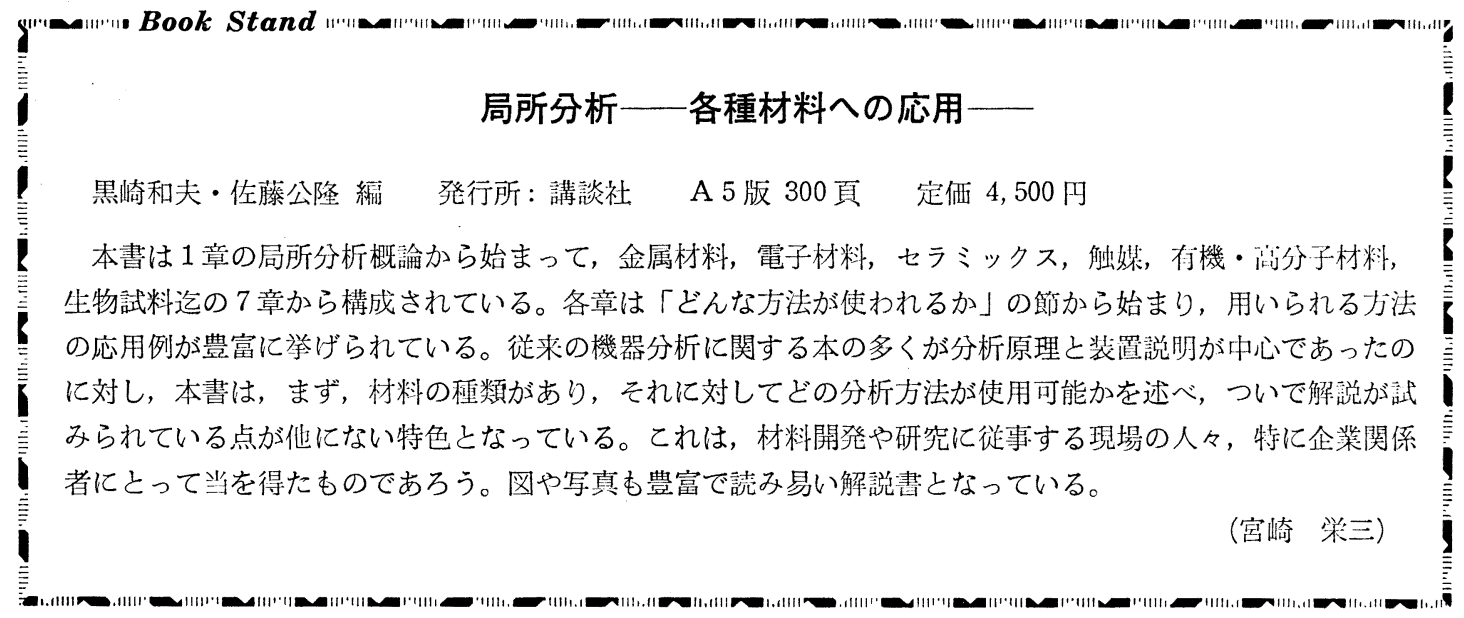

